\title{
1. Introduction: voices, preconditions, contexts
}

\section{Rafael Ziegler}

The danger of an uncritical and exclusive promotion of a free and market-based (social) system is evident. There are domains where the state has a duty to take action and to ensure the basic security of its citizens. But without a permanent input to the state system of new ideas from outside, even this legitimate domain can do more harm than good. (Judy Korn, Chapter 3 in this volume, p. 51)

Social entrepreneurship has become a source of hope, but we are like water-tap users who know little about the origin of the source. Social entrepreneurship is said to be made of ideas that are tried out rather than proclaimed, ideas that are pushed through by initiatives belonging to individuals rather than multinational mega-organisations, ideas that are proposed in languages that are culturally diverse and not necessarily professionally polished, ideas that speak of pervasive social inequalities and exclusions, of ecological problems and risks, and ideas that do not speak of these issues as inevitable predicaments but as challenges that call for societal transformations. Who or what makes all this possible? Social entrepreneurs are said to have innovative solutions to pressing social problems; they are characterised as ambitious and persistent; they are said not to rely on business and government for the realisation of their ideas, and to aim at wide-scale, systemic change. ${ }^{1}$ These social entrepreneurs are promoted by support organisations, the media, companies and policy-makers. They have become increasingly familiar, branded and politicised actors. How has this happened? What kind of impact do social entrepreneurs seek? What impact do social entrepreneurs have? And, is it possible not only to learn about social entrepreneurs, but also to become one?

This anthology offers extended discussions of these questions - except for the last one. Oscar Wilde quipped that 'the best things in life cannot be taught'. Whether social entrepreneurship belongs to the 'best things in life' is no doubt a question of individual judgment. But the obstacle to 'teaching' social entrepreneurship is not this question of taste: the frequent claim that people are 'born' as social entrepreneurs is. Social entrepreneur Orlando Rincón Bonilla says: 'It's genetic. You can walk into a room full 
of people, and pick the entrepreneurs out in seconds. It's something about the look in their eyes.' ${ }^{2}$ Is it therefore only possible to 'pick' and 'support' people who already are social entrepreneurs, but impossible to teach social entrepreneurship in a vocational sense? The question points to a paradox: 'social entrepreneurs' are presented as special people, as the contemporary heroes and leaders, and at the same time social entrepreneurship indicates a universal ideal: 'everyone a changemaker' (Drayton, 2006). The paradox points to tensions between an elite and a democratic ideal of equality, between an exclusive network and an inclusive vision. These tensions resonate widely, and they call for a consideration of the contexts and presuppositions of social entrepreneurship. Why is social change conceptualised in these individualist terms? Could there be alternative conceptualisations? What is the cultural significance of this phenomenon?

Even if it would be accepted that some people are 'born' as social entrepreneurs, there remains the question: what preconditions are conducive or even necessary for them to act as social entrepreneurs? On the one hand, if Mozart had been born into a family with no musical instruments, no money and no interest in a classic music education for children but with much love for Viennese bakery, would he have lived the life of a 'conceptual entrepreneur' ${ }^{\prime 3}$ (be it in music, or in bakery)? On the other hand, did his contemporaries call him an 'entrepreneur'? In short, what are the cultural, social and economic preconditions of social entrepreneurship? Social entrepreneurs may embody the power of ideas, but ideas also have power over social entrepreneurs.

In a sense it does not matter whether we think of social entrepreneurs as 'born' social entrepreneurs or as 'becoming' ones - either way they will have to act in specific contexts of local and global norms that they fight for or struggle against; and that they will face terminology choices that may foster one cause better than another; for example, rhetoric that primarily focuses on the individual, on the social entrepreneur as 'hero', even though social entrepreneurship requires organisation and participation. These contexts are worthy objects of study, even if one is not a social entrepreneur or does not want to become one, for they concern basic contexts of the organisation of work today.

Accordingly, this anthology proposes in depth studies of the preconditions (Part II) and contexts (Part III) of social entrepreneurship. Neither the study of preconditions nor the study of contexts will answer the question whether it is possible to ignite this 'look', this 'sense of excitement' and of 'boundless fascination' in everyone's eyes. However, this anthology offers contributions written by social entrepreneurs (Part I): reflections on their work, on social entrepreneurship and on the relation of social entrepreneurship to the state. Taken together, the three parts will help to better 
understand what the 'looks' are all about, what social entrepreneurs get 'excited' about, and consequently whether one would even want (everyone) to be excited in this way.

In music, an 'introduction' usually sets the 'tone' for a piece of music. The 'piece' here is the real world of social entrepreneurship. Let me explain the choice of perspectives selected for this introduction.

\section{A CONTRIBUTION TO THE SOUND OF INNOVATION}

The discussion of social entrepreneurship flows together from a number of quite different types of texts coming from different positions and practices. At least six prominent perspectives can be distinguished. ${ }^{4}$ These distinctions help explain the choice of texts in this anthology - and they help listen to the 'sound of innovation' as the interplay of different voices rather than just as the confusing 'noise' of a field (under)mined by multiple definitions.

1. Social entrepreneurs: some discussions of social entrepreneurship are written by social entrepreneurs. In comparison to the other perspectives listed below, such texts are relatively rare (see also the section on Part I below). ${ }^{5}$

2. Social entrepreneurship support organisations: a large number of texts on social entrepreneurship, including some of the most widely read ones, come from (or are strongly influenced by) the organisations that select and support social entrepreneurs. ${ }^{6}$ These texts tend to promote social entrepreneurship, not least because organisations such as Ashoka and the Schwab Foundation have an institutional interest to attract funds and other means of support. Catchy tunes are needed, and the promotion ranges from case studies of (typically successful) social entrepreneurs to manifestos. Here is one example from William Drayton, the founder of Ashoka, who has probably done more than anyone else to promote social entrepreneurship:

The most important contribution any of us can make now is not to solve any particular problem, no matter how urgent energy or environment or financial regulation is. What we must do now is increase the proportion of humans who know that they can cause change. And who, like smart white blood cells coursing through society, will stop with pleasure whenever they see that something is stuck or that an opportunity is ripe to be seized. Multiplying society's capacity to adapt and change intelligently and constructively and building the necessary underlying collaborative architecture, is the world's most critical opportunity now. Pattern-changing leading social entrepreneurs are the most critical single factor in catalysing and engineering this transformation. (Drayton, 2006: 7) 
3. Journalism: book-length studies of social entrepreneurs have been written by journalists, ${ }^{7}$ well-known daily newspapers such as the New York Times or the Frankfurter Allgemeine Zeitung have published 'faces' and features; on television the Public Broadcast Service has aired a 'New Heroes' series that tells 'the dramatic stories of 14 daring people' ${ }^{8}$ These are texts (and films) that feature successful entrepreneurs, and they are often written and produced in close co-operation with the social entrepreneurship support organisations.

4. Academia: management studies, but increasingly also researchers from other disciplines, including economics, sociology and political science, have made social entrepreneurship an emerging field of research. Social entrepreneurship has been examined inter alia via the lenses of strategic management, social movement theory and democratic theory. ${ }^{9}$ Inevitably, the tone is more sceptical. Social entrepreneurship reverberates from theories of agency, value, democracy and so forth. Historical comparisons and conceptual contrasts are drawn, theoretical analyses of the phenomenon are made.

5. Business: successful entrepreneurs have shown interest in social entrepreneurship. For example Jeff Skoll, first president of eBay, founded in 1999 the Oxford-based Skoll Foundation with a mission to 'advance systemic change to benefit communities around the world by investing in, connecting and celebrating social entrepreneurs'. ${ }^{10}$ Many companies support social entrepreneurship support organisations, financially but also via pro bono consultancy and other means.

6. Fiction: fiction, written or filmed, offers rich descriptions and very comprehensive perspectives. Consider how William Dean Howells, in his The Rise of Silas Lapham, lets his entrepreneur speak. 'I believe in my paint', says Silas Lapham,

I believe it's a blessing to the world. When folks come in, and kind of smell round, and ask me what I mix it with, I always say, 'Well, in the first place, I mix it with Faith, and after that I grind it up with the best quality of boiled linseed oil that money will buy'. (Howells, 1884-85 [1982]: 16)

Fiction humbles academics and journalists by revealing just how little they have been considering so far, and how many other factors they might still have to consider. In fiction, the characters belong to families - something they would not seem to belong to for anyone who just read the accounts of (most) academics and journalists. They have social aspirations and meet social pressures, and these familial-social ties stand in a complex relation to their work. The 'faith' in his 'paint' is situated in Howells' novel in a larger 'economy of pain' that exhibits a dynamic between family life and economic life. Apart from novels, 
biographies and autobiographies should also be mentioned. Along with novels and films, they play a (largely unacknowledged role) for the way in which people in 1-4 preconceive the 'story of a life'.

The point of drawing these distinctions is not to say that any perspective is better than the others. And in practice these distinctions are blurred. But the distinctions help explain the choices made when producing this book, as well as offer a trivial, yet important consideration for thinking about social entrepreneurship.

This anthology draws on source one (social entrepreneurs) and source three (academics). The texts by social entrepreneurship organisations, journalists and business are readily available via the Internet and other mass media. But as noted above, thinking about social entrepreneurship calls in particular for exploring the tension between social entrepreneurs, and the preconditions and contexts of social entrepreneurship; between individual (and group) agency and social structure. Accordingly, this anthology has been organised to include a part with contributions by social entrepreneurs, and parts that discuss preconditions and contexts drawing on the work of academic research.

There is therefore no fiction in this anthology; partly for the same reason that novels are easily available from libraries and bookstores, but also because their comprehensive theorising of the life of entrepreneurs of work and family, reality and faith, individual story-telling and novel structure - does not come in 'chapters'. Still, a more systematic discussion of fiction in relation to social entrepreneurship ought to be a challenge for future research on social entrepreneurship. The same holds for an account of the business perspective. Neither a big business entrepreneur nor a corporation has been invited to contribute to this anthology. These actors are able to effectively communicate their views and fund research, and in this sense are sure to play a role in the way all of us already understand social entrepreneurship. More interesting therefore, and there seems to be a real gap in literature, would be an analysis of the influence of business on social entrepreneurs and the social entrepreneurship organisation - a task for academics and journalists. ${ }^{11}$ The chapter by Daniel Hjorth in this anthology is a step in this direction.

Keeping these distinct perspectives in mind does not only explain the choices made for this anthology and how it seeks to contribute to the already existing 'sound of innovation', but it also helps with the study of social entrepreneurship. Consider this passage from Drayton:

By 1700 , however, a new, more open architecture was beginning to develop in northern Europe: entrepreneurial/competitive business facilitated by more 
tolerant, open politics . . the West broke out from 1,200 years of stagnation and soon soared past anything the world had seen before ... However, until 1980, this transformation bypassed the social half of the world's operations. Society taxed the new wealth created by business to pay for its roads and canals, schools and welfare systems. There was no need to change . . . the social sector had felt little need to change and a paymaster that actively discouraged it. Hence, the squalor of the social sector. Relative performance declining at an accelerating rate. And consequent low repute, dismal pay, and poor self-esteem and élan. (Drayton, 2006: 5f)

Taken as the statement of a historian, this would seem to be a bold generalisation, and it would surely infuriate all other historians. But taken as a manifesto promoting social entrepreneurship - 'everyone a changemaker' - bold generalisation will be expected, and the focus turns to the political position proclaimed, and to the metaphors and allusions animating the text rather than its historical accuracy. But of course historical accuracy may then well play an important role for examining the position taken in the manifesto (see the chapter by Boddice in this volume). Trivially but certainly not always observed, learning about social entrepreneurship requires taking into account the position and interests of the various voices animating the debate, including one's own. The 'sound of innovation' is one in which we all participate.

\section{PART I: VOICES}

But some participate more than others. In Part I of this anthology, people who accept being called 'social entrepreneurs' speak about what they do and what this designation means for them. And people with a social mission, who are entrepreneurial, but who do not accept this title, speak about what they do and what this title means for them.

The contributors, men and women, work on social and environmental issues in Eastern and Western Europe. Judy Korn from Berlin, Germany, co-directs the Violence Prevention Network that seeks to reduce the rate of racially and religiously motivated youth crime. Michal Kravcik belongs to the first generation of Slovak social entrepreneurs. For more than a decade, he and his non-governmental organisation (NGO) People and Water have worked towards an integrated, decentralised and ecologically sound water management in Slovakia. Krzyzstof Stanowski is Deputy Minister of Education in Poland - he was offered this work in no small part due to his prior work, supported by an Ashoka fellowship, as programme director and then president of the Warsaw-based Education for Democracy Foundation operating in Eastern Europe and Central Asia. By contrast, 
Philipp Albers and Holm Friebe from the Zentrale Intelligenz Agentur in Berlin are not 'fellows' of any social entrepreneurship organisation (and do not seem to be eager to become 'fellows' of any larger organisation). However, they have set up their own organisation motivated by a vision of large-scale change in the labour world from permanent employment to flexible networks of self-employed people. They seek to co-design and contribute to this social change with new forms of collaboration.

What is it like to be a 'social entrepreneur'? All contributors to this part have been invited to contribute to the anthology, and were asked to write about (a) their initiatives, (b) their biography, (c) social entrepreneurship and (d) how they view their work in relation to the state. Their contributions follow this four-part structure. Korn and Kravcik have written texts; Albers and Friebe, and Stanowski preferred to conduct conversations on these themes, on the basis of which we together produced an edited protocol.

Accordingly, this part seeks to contribute to the understanding of social entrepreneurship in three ways:

1. Often the sound of innovation is presented as a concert for orchestra and soloists - but the soloists are missing. As noted, texts written by social entrepreneurs are relatively rare whereas there is an abundance of texts written 'about' them. Part I offers one way to ask how these 'persistent' and 'ambitious' creatures correspond to the accounts and definitions of support organisations and academics.

2. Unlike the profiles available from social entrepreneurship support organisations, the contributions in Part I include a reflection on social entrepreneurship as well as on the relation between social entrepreneurship and the state.

3. Finally, this part also points to a domain of co-operation between social entrepreneurs and universities, research institutes and so forth. On one level, there is the study of social entrepreneurship as a phenomenon in its own right, on another level, there are the specific ideas put forward by specific social entrepreneurs. Kravcik and his collaborators offer a bold new water paradigm. Korn and her collaborators propose a pedagogy of responsibility. Albers and Friebe argue that we are about to enter a new regime of social hygiene that will force companies and each of us to rethink and re-organise work-life. The innovations proposed in these environmental, social and economic dimensions are necessarily as important as the study of social entrepreneurship on the general level. These specific innovations are at the core of whatever change this actor achieves, and why others would like to learn about it, support it and so forth. But how are 'powerful' ideas made? Part I 
suggests an important dialogue with universities and research centres (see also below).

\section{Social Entrepreneurship as a Contested Concept}

The approach taken in this first part, notwithstanding one dissenting voice (Albers and Friebe), implicitly endorses the Ashoka approach to social entrepreneurship already cited in the first paragraph of this introduction. This organisation is an example of widely recognised best practice in the field: whatever social entrepreneurship is or ought to be, accredited Ashoka fellows should be considered.

If no 'definition' of 'social entrepreneurship' has been offered so far, it is certainly not because there is a lack of proposals. To the contrary, 'social entrepreneurship' almost inevitably attracts concerns about 'definition'.

Social entrepreneur Muhammed Yunnus speaks of a new type of person,

who is not interested in profit maximisation. He is totally committed to make a difference to the world. He is socially-objective driven. He wants to give a better chance in life to other people. He wants to achieve his objective through creating and supporting sustainable business enterprises. Such businesses may or may not earn profit, but like any other business they must not incur losses. ${ }^{12}$

The social entrepreneurship support organisation Schwab describes the social entrepreneur as 'a pragmatic visionary who achieves large scale, systemic and sustainable social change through a new invention, a different approach, a more rigorous application of known technologies or strategies, or a combination of these'; social entrepreneurs, the foundation adds, 'combine the characteristics represented by Richard Branson and Mother Teresa'13 (social entrepreneurs, then, are also a challenge to the imagination). Professor Johanna Mair, a contributor to this volume, and Ernesto Noboa define social entrepreneurship as 'the innovative use of resource combinations to pursue opportunities aiming at the creation of organisations and/or practices that yield and sustain social benefits' (Mair and Noboa, 2006: 122).

The definition by Mair and Noboa is taken from an anthology of recent social entrepreneurship scholarship. It was not the only choice available from this anthology: ten definitions are respectively used by its contributors (Mair et al., 2006: 4f). A large number of proposed definitions are a familiar phenomenon from other concepts that are not only novel, but also important for a number of diverse actors. 'Sustainable development' is a well-known example. They are 'contested concepts' (Jacobs, 1999) in that they function as the 'common currency' of quite different actors from government, civil society, social movements and business. Their use is possible, 
because contested concepts have two levels of meaning. One level is unitary and vague; it contains core ideas that are substantive and non-redundant. On a second level, definitions are precise and contested.

The first level brings together concepts that have not been related before in this way, but whose combination is compelling. For 'sustainable development' this is the need to integrate 'environmental' and 'economic' concerns; for 'social entrepreneurship' it is the integration of 'social objectives' with an 'entrepreneurial approach'. No doubt, this is 'vague', but the point is that none of the actors could discuss 'social entrepreneurship' focusing exclusively on 'social mission', nor would it be vice versa plausible to focus exclusively on business and earned income. An exclusive focus on social mission will lead to questions on how these actors are different from social service, charity, and social activism; an exclusive focus on 'entrepreneurship' is likely to produce the response that social entrepreneurship is really just a new form of business to promote itself and to enhance its public image. In short, all actors are forced to address both aspects. Judging from the various discussion of social entrepreneurship, this 'vague' level moreover includes the demand that the initiatives be 'sustainable', that they are 'innovative', that they aim at 'systemic change', that they address issues of 'equity' (at least at the level of needs) and/or 'environmental protection', that profit is not the priority and that those supported by the initiative are participants rather than 'mere victims' or 'objects'. To be sure, none of these demands are 'novel'. What makes 'social entrepreneurship' unique is that they must be discussed together.

At the second level, where the definition of social entrepreneurship is related to specific actions - a governmental grant programme, a fellow selection process or an academic research programme - more precise definitions of social entrepreneurship can be found, as well as their contestation. One example from academia is Francesco Perrini's distinction of 'two different schools of thought that have been developing regarding the SE definition' (Perrini, 2006: 6ff). What he calls the 'limited view' considers social entrepreneurship as belonging to theories pertinent to non-profits, what he calls the 'extended view' considers social entrepreneurship as a 'totally new, inter-sectoral field of study' (ibid.). But while there is then a 'contestation' between 'schools', both schools will have to address and interpret one way or the other the core concepts included on the 'vague level'. Disagreements over the 'meaning' of social entrepreneurship on this second level reveal the central arguments that the concept calls forth, and that unites people in contestation.

The specification offered on this second level issues from specific actions; different 'definitions' of social entrepreneurship must be seen in relation to the respective uses - the selection of fellows, a sociological research 
programme and so forth. If these different uses are noted, a diversity of 'definitions' is less surprising and maybe also less 'threatening' (considering the 'one-definition'-anxiety that preoccupies some in the field). However, this is certainly not to say that 'any' definition is as 'good' as any other (just as any 'social' mission is not necessarily 'good'). Rather, the claim is that these contestations over the approach are an essential part of the political arguments social entrepreneurship attracts. As Rob Boddice notes in this volume, much remains to be done to clarify these arguments.

\section{PART II: PRECONDITIONS}

That management and entrepreneurship are clearly distinguished today is not least due to one of the greatest and most influential twentieth-century economists, Joseph Schumpeter. He proposed an economic theory, which in stark contrast to neoclassical equilibrium theory puts a fundamental emphasis on historical change. Unlike Marx, he did not describe this change in terms of class struggles (and their relation to the conditions of production). Instead, Schumpeter put key emphasis on the role of the entrepreneurs and the entrepreneurial function for economic development.

This focus made him 'the' theorist of entrepreneurship and later of 'business' innovation studies, widely read, and often only partially read. In his chapter, Richard Swedberg carefully sets out the elements of Schumpeter's full model of entrepreneurship: the motivation of entrepreneurs, innovation, resistance, profit and the structural effect of the innovation on the business cycle.

Swedberg then updates the model, and generalises it to non-economic entrepreneurship, including social entrepreneurship. On this Schumpeterian account social entrepreneurship is defined 'as the pushing through or the successful introduction of social change through a new combination of elements that make up some way of doing things' (see Figure 6.6 in Swedberg's chapter). He reconsiders the elements of the full model of entrepreneurship in this new context and thereby offers a method for a systematic approach to the study of social entrepreneurship initiatives.

Schumpeter wrote the first edition of his famous Theory of Economic Development in 1811, that is, towards the end of the so-called 'golden age of capitalism' (the period roughly from 1880 to 1920). During this period entrepreneurs entered the stage, and were given literary monuments as in William Dean Howells' The Rise of Silas Lapham from 1885. But The Rise of Silas Lapham begins with the 'economic' rise of the entrepreneur - and it ends with his economic decline, outcompeted by a new corporation and financial capital (and in Schumpeter's account, the large-scale corporation 
and its administrative system is a mortal threat to the entrepreneur, see especially Schumpeter, 1942 [1977]).

In her chapter, Eva Illouz tells a story of this 'other' economic history, not that of entrepreneurship, but of management and the corporation. She notes that during the 'golden age of capitalism' production was increasingly standardised, organisation bureaucratised and the labour forces incorporated into large corporations with thousands of employees. She invites us to think deeply about the culture of management coming about with the corporation, and the role of empathy that has evolved within it.

Rather than juxtaposing management and entrepreneurship, this chapter invites us to study the culture of management as a profound and influential source for the 'empathy' stressed in the social entrepreneurship literature. Indeed, it describes the rise of a 'feminine' model of emotional control and empathy in the modern corporation that even in 'translation' is likely to have a strong effect on social entrepreneurs. Her account of the emerging 'corporate' self leads her to a final paradox: the suspension of emotions as a condition of co-operation and communication.

If the work of cultural sociologist Eva Illouz raises deep questions about the antecedents of currents social entrepreneurship discussion in the twentieth-century American culture of management, historian Rob Boddice invites readers to directly question a number of prominent features of social entrepreneurship: its claim to novelty, the precise meaning of the 'social' and 'ethical' in social entrepreneurship as well as the motivation of social entrepreneurs.

Boddice offers case studies of the British industrialist and visionary Robert Owen, the French social Catholic Léon Harmel, the American tycoon-philanthropist Henry Ford and the American high-tech computer entrepreneur William Norris in support of his argument that social entrepreneurship has its roots in a variety of movements stretching back to the industrial revolution. Reconsidering this history, he argues, sensitises us to the ideological forces that moulded social entrepreneurship. In particular, the historical perspective shows that a mere attributing of 'ethical' motives and justifications to these past actors conceals the variety of religious, utilitarian, authoritarian and communitarian motives and values that inspired or 'called' forth these actors. But if in retrospect these past entrepreneurs with a 'social' vision do not appear straightforwardly good, what then, by analogy, about the 'social' and 'ethical' claims of contemporary social entrepreneurs? Boddice urges social entrepreneurs and those supporting them to reflect on the sources of their values, and how they are held accountable for the values they promote.

His spirited, historically informed attack on some aspects of the presentation and self-understanding of (some) social entrepreneurs and the 
organisations supporting them is likely to meet some likely equally spirited responses on questions that no doubt are important for a deeper understanding of social entrepreneurship: can 'value neutrality' be assumed or even achieved as a possible goal? Do tycoon philanthropists such as Henry Ford, who got an entire society 'moving' (Boddice), not meet all the criteria of social entrepreneurship, and if so what does this imply for current 'corporate social responsibility' and 'corporate citizenship'? Finally, as a basic question of precondition, is social entrepreneurship an epilogue to what Max Weber called the 'spirit of Capitalism'?

\section{PART III: CONTEXTS}

Joseph Schumpeter places his analysis of entrepreneurship in a theory of (economic) development. The choice is conspicuous; it points to an important context of social entrepreneurship, that is, the role of social entrepreneurs in so-called 'developing' countries (see the chapter by Seelos and Mair), and in so-called 'developed' ones (see the chapters by Grenier, and by Hjorth). Is 'social entrepreneurship' an alternative to more traditional development 'aid' in the former? Does it advance sustainable development there? And does social entrepreneurship 'also' have a place in 'developed countries"? If so, what kind of place is this?

Before social entrepreneurship is put into this developing/developed context, a chapter (by Ion Bogdan Vasi) re-asks, for the purposes of this anthology, the methodological question that Schumpeter had already put forward with so much methodological sensitivity: how to study (social) entrepreneurship? He develops his answer drawing on the sociology of entrepreneurship (issuing from Weber and Schumpeter) and the theory of social movements. His chapter 'New heroes, old theories? Toward a sociological perspective on social entrepreneurship' notes the tendency to frame social issues in terms of individuals in the post-Thatcher/Reagan welfare states. The focus on individuals as the primary source of (their respective) responsibility for unemployment, is the focus on individuals as 'heroes' taking responsibility for social change. But from a sociological perspective such a focus is inadequate, Vasi argues, and leads to a futile search for the 'entrepreneurial personality'.

According to Vasi, social movement research and the sociology of entrepreneurship offer tools for a deeper analysis of the phenomenon. The study of social entrepreneurs - of 'success stories', but also the 'failures' of unsung 'heroes' - should take into account social entrepreneurs' perception of political and discursive opportunities, their mobilisation of organisational resources, and their interpretative work. 
Consider Victoria Hale, founder of the Institute for One World Health that develops safe and affordable medicines for people with infectious diseases. ${ }^{14}$ On the 'hero perspective', we should focus on the inspiration, creativity and courage of Victoria Hale. However, Vasi argues, in order to explain the success of the institute so far we have to focus on how it overcame distrust from government and business: collaboration with the National Institute of Allergy and the World Health Organization provided moral and financial resources.

But these tools from social movement research are not only important for the analysis of success and failure of social movements, Vasi argues, they also sensitise for the difficult task of assessing the 'success' of social entrepreneurs. The work of social entrepreneurs cannot be measured simply in terms of the growth of the respective organisation, and its products and services. Rather social entrepreneurs' success in meeting social goals can depend on successful administrative and organisational reforms that make social entrepreneurship akin to social activism rather than business entrepreneurship.

'Sustainable development' is not only a well-known contested concept, it also offers an important context for locating social entrepreneurship as Christian Seelos and Johanna Mair show in their contribution 'Hope for sustainable development: how social entrepreneurs make it happen'. They analyse sustainable development in terms of three clusters of goals: (1) satisfying basic needs, (2) creating communities to establish norms, rights and collaborative behaviour as a prerequisite for participating in social and economic development, and (3) translating the more abstract needs of future generations into action today. These goals have become (at least partly) internationally agreed on goals via the Millennium Development Goals adopted by the United Nations. ${ }^{15}$ However, they argue that traditional efforts to achieve such goals, roughly speaking the respective national governmental implantation of internationally agreed on and internationally financed plans, have failed. More financial aid to the central administrations can be insufficient as these are already overwhelmed by the existing programmes. In particular in poor countries, there are problems with effective government and market structures. Finally, they point out that sustainable development is a complex challenge that makes internationally agreed on plans and related top-down efforts difficult to implement. However, they argue that there is also (some) hope. They find that the social entrepreneurs contribute to all of the basic elements of sustainable development.

The complement to Mair and Seelos's focus on sustainable development in 'poor' countries of the 'developing world' is a focus on the 'rich' countries of the 'developed' world. The slowdown of post-World War II 
economic growths rates along with persistent, high unemployment offered arguments for restructuring governmental administrations, for the privatisation of goods and services, and for changes to the social insurance system. Needless to say, this restructuring did not meet all social needs (and moreover created new ones). But efforts to privatise goods and services, and to restructure social services with a 'neo-liberal' twist, provided fertile soil for the emergence of social entrepreneurs in the 'developed' world.

In her chapter, Paola Grenier traces the rhetoric of social entrepreneurship in the UK, where the 'enterprise culture' of Thatcherism was followed by policy prominence given to social entrepreneurship with the election of the New Labour Government in 1997. Prime Minister Tony Blair announced: 'We will be backing thousands of social entrepreneurs - those people who bring to social problems the same enterprise and imagination that business entrepreneurs bring to wealth creation' (cited by Grenier, section 10.1 of her contribution to this volume). The rhetoric of social entrepreneurship in the UK, as elsewhere, is one of sweeping change. But Grenier also examines the practice of social entrepreneurship in the UK: the policy interventions of the UK government (through the Active Communities Unit, the Millennium Awards Scheme, the Community Champions Fund, and the granting of a $£ 100$ million endowment to the foundation for social entrepreneurs, UnLtd), and actions of social entrepreneurship support organisations such as Ashoka, the School for Social Entrepreneurs and the Community Action Network. She concludes that in the UK context, the understanding of social entrepreneurship based on innovative individuals (as pioneered by Ashoka) has been marginalised. The charismatic social entrepreneur seeking transformative change was not so appealing to policymakers keen on 'modernisation' and 'reform'. They were more attracted by 'social enterprise' as a balance of social and economic goals, and in 'social entrepreneurship' as a mechanism for local community development.

Her analysis of the rhetoric and practice of social entrepreneurship therefore leads Grenier to the conclusion that, in the UK, social entrepreneurship has not given rise to the wide-ranging innovations announced in the 1990s, nor to coherent social entrepreneurship policy interventions. In practice, social entrepreneurship took place on the community level, involving the labelling and support of several thousand 'social entrepreneurs' who carried out small-scale social initiatives. Surprisingly then, even if the general discourse context is initially shaped by neo-liberal, Thatcherite, ideas the 'practice' of 'social entrepreneurship' in the UK is much informed by a small-scale communitarian tendency in policy discourse.

Daniel Hjorth, in his chapter 'Entrepreneurship, sociality and art: reimagining the public', analyses 'social entrepreneurship' more generally in terms of the enterprise discourse. For him, 'social entrepreneurship' 
stands for a tamed version of entrepreneurship that promises solutions to social problems, and that simultaneously re-describes these problems as economic problems subject to management knowledge.

Do we have to move beyond social entrepreneurship? At stake, according to Hjorth, is the possibility of a public that offers ways of living based on principles of equity and abundance, a public that does not unite only for reasons of self-interest and scarcity. Such a future public, he argues, requires creative and playful actors that break with contemporary economic routines and that invent new forms of living together. Hjorth calls these actors 'public entrepreneurs'.

But are there, and will there be public entrepreneurs? Hjorth suggests that art with its destabilising function could provide the space for public entrepreneurship. Art, Hjorth proposes, has a democratic force that addresses anyone, a force that can stop each one of us, make us re-think, and thereby prepare a space for re-imagining the public.

\section{EDUCATION}

This anthology originates in a student proposal to discuss social entrepreneurship at the university level $;{ }^{16}$ it led first to a week-long conference on social entrepreneurship, then to a social entrepreneurship seminar and, finally, to this anthology. More than half of the contributors gathered in this volume attended the week and/or the seminar.

Among those participating were three of the contributors to Part I (and the fourth one indirectly ${ }^{17}$ ). There is not only an interest from students to learn about social entrepreneurship, social entrepreneurs also have a strong interest in education. Stanowski's focus is primarily on a specific approach to education for democracy, for Korn political education is a basic component of her programme to reduce recidivism among right-wing extremist and religiously motivated offenders, and Kravick has organised a water university in an effort to disseminate and implement his approach (and as Boddice's chapter shows 'antecedent' figures such as Robert Owen and Léon Harmel also had strong views on education: Harmel considered religious education a condition of industrial development, Owen's projects included schools meant to build the character of the community members). These are all examples of a mission-oriented approach to education (although the mission varies from Christian views, to human rights to a New Water Paradigm). And the interest to learn about social entrepreneurship is no doubt partly due to this mission orientation.

Social entrepreneurship has become a source of hope - sources are the place where ground water flows off the ground, the spring of brooks that 
form the rivers flowing to the sea. But it is the sea that has provided perhaps 'the' image of science in the twentieth-century. Philosopher of Science Otto Neurath speaks of sailors on the open sea who must reconstruct their ship, but are never able to start afresh with the best materials on a dock (Neurath, 1932-33: 206). The metaphor of science at sea is one of survival and discovery - and one of independence from the land and its concerns. The metaphor suggests, therefore, that science and science education is at odds with the social mission based education.

However, in keeping with the image, there is no reason why the ships and their science-sailors could not return to ports, at least from time to time; likewise there is no reason why those with strong missions on the land could not come to the coast, at least from time to time. In this light, social entrepreneurship education at the university level is a natural meeting point of 'land' and 'water'. It is the 'wetland' that is known as a source of life, and as an often treacherous ground with foul smells. This anthology is a hybrid that brings together social entrepreneurs and academics, that begins with Michal Kravick's call 'to return the lost water to the continents', includes discussions of the paths and of the dead ends of social entrepreneurship and ends with a chapter on 'hope for sustainable development'.

I think that social entrepreneurship is one interesting possibility within education for sustainable development, and that the collaboration of social entrepreneurs with academic researchers on thematic issues could be extended much further - but of course only under the watchful, synthesising eyes of students.

\section{NOTES}

1. See www.ashoka.org/social_entrepreneur, last accessed 10 July 2008.

2. Cited in Elkington and Hartigan (2008: 10). David Bornstein introduces the founder of Ashoka in this way: 'Bill Drayton might be someone you might expect to find in a library on a Saturday night. He is inordinately thin. He wears out-of-fashion suits, thick glasses, and wallabies. His hair is limp, his skin a little pale, his tie is generally askew. Yet, his eyes convey a sense of excitement about life, a seemingly boundless fascination with the world that is reminiscent of a young child's curiosity' (Bornstein, 2004: 12). See also the comments by Krzyzstof Stanwoski in this volume.

3. I take this term from Elkington and Hartigan (2008: 13f).

4. This list is not exhaustive; consider for example policy-makers, and think tanks close to them. As Paola Grenier's chapter (in this volume) shows, these actors played an important role in the UK's 'history of social entrepreneurship', and what is so labelled, but I am not sure to what extent, at this point in time at any rate, the importance of policy-makers and think tanks in UK history can be generalised to other countries. See also the discussion of social entrepreneurship as a contested concept below. A further perspective would be that of other civil society actors.

5. See for example Yunnus (2006). 
6. These organisations include Ashoka (1472 entrepreneurs in 48 countries); Echoing Green ( 371 fellows in 30 countries); LEAD (1402 Fellows in 70 countries); Avina (324 partners in 20 countries) and the Schwab Foundation (78 members in 30 countries). Numbers from Grenier (2006: 128). For lists of social entrepreneurship support organisations also see Perrini (2006: 13) and Nicholls (2006: 10).

7. A pioneer publication is Bornstein (2004). It stands at the beginning of what appears to be almost a distinct genre. See for example Stefanska and Hafenmayer (2007), Koch (2007), Elkington and Hartigan (2008). Of course these books vary considerably in terms of the depth of analytical framework for presenting social entrepreneurs. Still, already by their titles all of them invite to learn something about special people: unreasonable people, future-makers, change-makers, social capitalists.

8. www.pbs.org/opb/thenewheroes/index.html, last accessed 10 July 2008.

9. For lists of university centres devoted to social entrepreneurship see Perrini (2006: 12) and Nicholls (2006: 8), as well as the online university network (www.universitynetwork. org/node/310, last accessed 10 July 2008).

10. See www.skollfoundation.org, last accessed 10 July 2008.

11. However, there is research on corporate social entrepreneurship. See Austin et al. (2006).

12. www.grameen.com/bank/socialbusinessentrepreneurs.htm, last accessed $10 \mathrm{July} 2008$.

13. www.schwabfound.org/whatis.htm, last accessed 10 July 2008. Prior to their clarification of the term 'social entrepreneur' the foundation writes: 'Social entrepreneurship is 1) about applying practical, innovative and sustainable approaches to benefit society in general, with an emphasis on those who are marginalised and poor, 2) a term that captures a unique approach to economic and social problems, an approach that cuts across sectors and disciplines, 3 ) grounded in certain values and processes that are common to each social entrepreneur, independent of whether his/ her area of focus has been education, health, welfare reform, human rights, workers' rights, environment, economic development, agriculture, etc., or whether the organisations they set up are non-profit or for-profit entities.'

14. See www.oneworldhealth.org/, last accessed 10 July 2008.

15. 1. Eradicate extreme poverty and hunger (inter alia: reduce by half the proportion of people living on less than one US dollar a day; reduce by half the proportion of people who suffer from hunger). 2. Achieve universal primary education (inter alia: ensure that all boys and girls complete a full course of primary schooling). 3. Promote gender equality and empower women (eliminate gender disparity in primary and secondary education preferably by 2005 , and at all levels by 2015). 4 . Reduce child mortality (reduce the mortality rate among children under 5 by two-thirds). 5 . Improve maternal health (reduce by three-quarters the maternal mortality ratio). 6. Combat HIV/AIDS, malaria, and other diseases 7. Ensure environmental sustainability (inter alia: reduce by half the proportion of people without sustainable access to safe drinking water. 8. Develop a global partnership for development. See www.un.org/millenniumgoals/, last accessed 10 July 2008.

16. See State of the World Week 2007 at the European College of Liberal Arts in Berlin: http://swwe.ecla.de/, last accessed 4 August 2008.

17. One student wrote her final essay on Judy Korn and the Violence Prevention Network.

\section{REFERENCES}

Austin, J., H.B. Leonard, E. Reficco and J. Wei-Skillern (2006), 'Social entrepreneurship: it is for corporations, too', in A. Nicholls (ed.), Social Entrepreneurship, Oxford: Oxford University Press, pp. 169-80. 
Bornstein, D. (2004), How to Change the World. Social Entrepreneurs and the Power of New Ideas, Oxford: Oxford University Press.

Drayton, W. (2006), 'Everyone a changemaker: social entrepreneurship's ultimate goal', Innovations - Technology, Governance, Globalization, Winter, 1-32.

Elkington, J. and P. Hartigan (2008), The Power of Unreasonable People - How Social Entrepreneurs Create Markets that Change the World, Boston, MA: Harvard Business School Publishing.

Grenier, P. (2006), 'Social entrepreneurship: agency in a globalizing world', in A. Nicholls (ed.), Social Entrepreneurship: New Models of Sustainable Social Change, Oxford: Oxford University Press, pp. 119-43.

Howells, W.D. (1884-85 [1982]), The Rise of Silas Lapham. Edited by D. L. Cook, New York: W.W. Norton.

Jacobs, M. (1999), 'Sustainable development as a contested concept', in A. Dobson (ed.), Fairness and Futurity, Oxford: Oxford University Press, pp. 21-45.

Koch, H. (2007), Soziale Kapitalisten. Vorbilder für eine gerechte Wirtschaft, Berlin: Rotbuch.

Mair, J. and E. Noba (2006), 'Social entrepreneurship: how intentions to create a social venture are formed', in J. Mair, J. Robinson and K. Hockerts (eds), Social Entrepreneurship, London: Palgrave Macmillan, pp. 121-36.

Mair, J., J. Robinson and K. Hockerts (eds) (2006), Social Entrepreneurship, London: Palgrave Macmillan.

Neurath, O. (1932-33), ,Protokollsätze', Erkenntnis, 3, 204-214.

Nicholls, A. (ed.) (2006), Social Entrepreneurship: New Models of Sustainable Change, Oxford: Oxford University Press.

Perrini, F. (ed.) (2006), The New Social Entrepreneurship, Cheltenham, UK and Northampton, MA, USA: Edward Elgar.

Schumpeter, J.A. (1942 [1977]), Capitalism, Socialism and Democracy, New York: Harper \& Row.

Stefanska, J. and W. Hafenmayer (2007), Die Zukunftsmacher. Eine Reise zu Menschen, die die Welt verändern - und was Sie von ihnen lernen können, München: oekom.

Yunnus, M. (2006), 'Social business entrepreneurs are the solution', in A. Nicholls (ed.), Social Entrepreneurship: New Models of Sustainable Social Change, Oxford: Oxford University Press, pp. 39-44. 